ISSN: 2224-0616

Int. J. Agril. Res. Innov. \& Tech. 2 (2): 48-53, December, 2012 Available online at http:// www.ijarit.webs.com

\title{
ASSESSMENT OF USE OF INDIGENOUS MAIZE STORAGE PRACTICES AMONG FARMERS IN ANAMBRA STATE, NIGERIA
}

\author{
E.N. Ajani* and E.A. Onwubuya
}

Received 13 November 2012, Revised 22 December 2012, Accepted 25 December 2012, Published online 31 December 2012

\begin{abstract}
The study assessed the use of indigenous maize storage practices among farmers in Anambra State, Nigeria. Data for the study was collected by the use of interview schedule from a sample of 60 respondents. Percentage, mean score and standard deviation were used for analyzing data collected for the study. Results revealed that the farmers were using indigenous technologies such as baskets, aerial (over fire) in the kitchen, bare floors, among others in storing maize. The respondents indicated that they stored maize cobs undehusked in order to overcome wastage and obtained information about indigenous storage of maize from parents and fellow farmers. Major problems militating against effective storage of maize include: attack of pests such as rodents and weevils, diseases, termite attack and use of poor quality storage materials. The respondents indicated that use of materials free from termite, clearing of surroundings against fire disaster; use of durable materials treated with insecticides will help to solve the problems. The study recommends that provision of appropriate and affordable storage structures should be made available to the maize farmers in order to avoid wasting of the produce under storage. This will help to ensure food security among rural farm households.
\end{abstract}

Keywords: Indigenous, Knowledge, Storage, Practices, Maize, Farmers, Anambra State, Nigeria

Department of Agricultural Extension, Faculty of Agriculture, University of Nigeria, Nsukka, Nigeria

*Corresponding author's email: lyneajani@gmail.com (E.N. Ajani)

\section{Introduction}

Maize is a major food for most households in Nigeria and the main source of income and employment for the majority of rural households. Food security and welfare of the farming population are dependent on the productive capacity of maize farmers (Wekesa et al., 2003). The importance of appropriate and readily available post-harvest storage practices for agricultural crops cannot be overemphasized in any development plan for increased food production and enhancement of food security. Adequate storage of farm produce remains paramount for preservation of farm produce for future consumption. Maize is the most important cereal in the world after rice and wheat (Eleweanya et al., 2005). It is used as staple food in developing countries, particularly in the tropics. It also serves as raw materials for many finished products.

A lot of mature, ready-to-harvest and harvested crops, especially maize are lost to spoilage, contamination, mould and pests in the field and on storage. Severe pest's infestation may cause losses of up to $50 \%$. The use of pesticides for control of pests is effective but not economical (Echezona and Iloba, 2005). Apart from not being economical, pesticides tend to have severe side effects on the environment (Grant and Tingle, 2002).
According to Uguru (1996), storage techniques or methods can be traditional or improved methods. Collinson (2001) stated that there is urgent need for intensified efforts to be geared towards provision of adequate and efficient storage facilities in order to avoid wastage of farm produce.

Maize production among small scale farmers in Nigeria may have declined due to agricultural reforms. The reforms which commenced in 1980s and is on-going stemmed from the structural adjustment programmes. This led to cut back in government expenditure including removal of subsidies on farm inputs. As a result, greater economic burden was placed on the small scale farmers (Nyangito and Karugia, 2006; Mochoge and Zriwa, 2004). In addition, the open maize market resulting from the agricultural reforms caused fluctuations in maize returns, exploitation by middlemen and low product prices (Kodhek, 2005). The Agricultural reforms thus pose greater risk for small scale maize farmers who are risk averse to adopt improved agricultural practices (Ogada, 2009).

Lack of suitable high yielding variety as well as poor knowledge about production practices are ascribed as main reasons for low productivity of maize in Nigeria. The productivity of maize per unit area could be increased by adopting recommended scientific and sustainable management practices using a suitable high yielding variety. 
Maize farmers in Anambra state are using certain local methods and techniques such as storing over fire in the kitchen, use of earthen pots, gourds, among others in preserving maize to be used for future consumption. The study therefore answers the following questions:

> What are the indigenous maize storage practices used by maize farmers in the study area?

> What forms of storage are used for maize? What are the reasons for storing maize?

$>$ What are the problems militating against effective storage of maize?

The specific objectives were to:

i. identify indigenous maize storage practices used by farmers;

ii. ascertain reasons for storing maize; and

iii. ascertain constraints to effective storage of maize among farmers.

\section{Methodology}

The study was carried out in Anambra State, Nigeria. There are four agricultural zones in the state, namely; Aguata, Anambra, Awka and Onitsha. Two zones namely: Aguata and Anambra were purposively used for the study. The State shares boundary with Enugu State on the north, Delta State on the south, Kogi State on the west and Imo State on the east. It has an estimated population of 4.18 million and land area of approximately 5,025 sq. $\mathrm{km} \quad$ (NPC, 2006). Majority of the farmers in the state are involved in the production of arable crops such as yam, cassava, cocoyam, maize, vegetables and raising of farm animals like sheep, goat, and poultry. Major perennial crops grown in the state include: oil palm, mango, oil bean, pear, breadfruit, among others. The population of the study comprised farmers in the two agricultural zones. Anambra zone is made up of four (4) extension blocks comprising 45 circles, while Aguata zone is made up of six (6) extension blocks, comprising 45 circles. Two blocks and six circles were selected respectively from the zones and circles using a simple random sampling technique. In each of the circles selected, ten farmers were selected randomly for the study. In general, the study comprised four (4) blocks and twelve (12) circles, giving a total of one hundred and twenty (120) farmers. The interview schedule used for data collection was divided into four sections based on the objectives. The first section sought information on socio-economic characteristics of the farmers. Respondents were asked to indicate their age, marital status, level of education, size of household, head of household, sources of farm labour, farming occupational status, size of land holding (hectares) and other non-farm occupations. The second section sought information on indigenous maize storage practices which include: storing over fire in the kitchen, storing on the floor, use of cribs, gourds, and earthen pots, among others. Section three sought information on reasons for storing maize. The respondents were asked to indicate reasons for storing maize. This includes: future consumption, source of income, avoidance of wastage and generate money during off-season periods. The fourth section dealt with problems militating against effective storage of maize. The respondents were asked to indicate the problems using a Likert-type scale of to a great extent (3), to some extent (2), to a little extent (1) and to no extent (0). The mean was 1.5; this was used to determine the cut off point. Data for the study were collected using interview schedule/ questionnaire. Percentage, mean score and standard deviation were used for data analysis.

\section{Results and Discussion}

\section{Socio-economic characteristics of respondents}

Data in Table 1 show that about $14 \%$ of the respondents were within the age bracket of 2029 years and $25.0 \%$ of them were aged $30-39$ years and 40-49 years, respectively. About 21.0\% of the farmers were within the age of $50-59$ years while $14.2 \%$ of them were aged 60 years and above. This indicates that majority of the farmers were in most productive ages, hence greater involvement in maize production.

Entries in Table 1 show that majority (69.2\%) of the farmers were married, while about $13 \%$ and $17.5 \%$ were single and widowed, respectively. This implies that most of the respondents have household's hence greater involvement in maize production as well as practicing storage practices for future consumption for household members.

About $20.0 \%$ of the respondents never had any form of formal education. Greater proportion $(30.0 \%)$ had attended primary school while $27.5 \%$ and $22.5 \%$ attended secondary school and tertiary institutions, respectively. Education is very important to the farmers; this will help them to participate in the farming operations as managers by storing and marketing maize, maintaining computer records, making purchases and helping with long term planning (Taylor, 1997).

About $44.0 \%$ of the respondents had a fairly large family size of 6-10 members, $40.8 \%$ of them had between 1 and 5 members, while $10.0 \%$ and $5.0 \%$ had $11-15$ and $16-20$ members, respectively. Thus, the large family size of 6-10 members constitutes the family labor which most of the respondents rely upon in carrying out certain tasks in the maize farm. 
Majority (64.2\%) of the farmers were heads of households while $35.8 \%$ of them had their husbands as heads of household. This shows that in the absence of men as heads of households, women are becoming increasingly involved in agriculture. This helps to make their families economically stronger as well as ensuring food security. FAO (2002) points out that there is a great increase in the proportions of households headed by women this had resulted to women taking more responsibilities in agricultural production. According to UNESCO (1991), women are the heads of one third of the world's households.

Most (70.8\%) of the farmers depended on their family members for provision of labour used in the farm; about $6.0 \%$ and $4.2 \%$ of them obtained assistance from their relations and friends, respectively. Hired labour was rated $51.7 \%$ while about $1.3 \%$ depend on exchange labour. This implies that most of the labour used in their farms comes from household members.

Most (55.8\%) of the farmers engaged in part-time farming while $44.2 \%$ were on full-time basis.

Table 1. Distribution of the respondents according to socio-economic characteristics $(n=120)$

\begin{tabular}{|c|c|c|}
\hline Characteristics & Frequency & Percentage \\
\hline \multicolumn{3}{|l|}{ Age (years) } \\
\hline $20-29$ & 17 & 14.2 \\
\hline $30-39$ & 30 & 25.0 \\
\hline $40-49$ & 30 & 25.0 \\
\hline $50-59$ & 26 & 21.7 \\
\hline \multirow{2}{*}{\multicolumn{3}{|c|}{ Marital status }} \\
\hline & & \\
\hline Single & 16 & 13.3 \\
\hline Married & 83 & 69.2 \\
\hline \multirow{2}{*}{\multicolumn{3}{|c|}{ Level of education (years) }} \\
\hline & & \\
\hline No formal education & 24 & 20.0 \\
\hline Primary school & 36 & 30.0 \\
\hline Secondary school & 33 & 27.5 \\
\hline Tertiary institutions (NCE, Polytechnic, University & 27 & 22.5 \\
\hline \multicolumn{3}{|l|}{ Size of household } \\
\hline $1-5$ & 49 & 40.8 \\
\hline $6-10$ & 53 & 44.2 \\
\hline $11-15$ & 12 & 10.0 \\
\hline $16-20$ & 6 & 5.0 \\
\hline \multicolumn{3}{|l|}{ Head of household } \\
\hline Husband & 43 & 35.8 \\
\hline \multirow{2}{*}{\multicolumn{3}{|c|}{ Sources of farm labour* }} \\
\hline & & \\
\hline Household members & 85 & 70.8 \\
\hline Relations & 8 & 6.7 \\
\hline Friends & 5 & 4.2 \\
\hline Hired labour & 62 & 51.7 \\
\hline Exchange labour & 16 & 13.3 \\
\hline \multicolumn{3}{|l|}{ Farming occupational status } \\
\hline Full-time & 53 & 44.2 \\
\hline Part-time & 67 & 55.8 \\
\hline \multicolumn{3}{|l|}{ Farm size (hectares) } \\
\hline$<1$ & 33 & 27.5 \\
\hline $1-2$ & 61 & 50.8 \\
\hline $3-4$ & 24 & 20.0 \\
\hline 5 and above & 2 & 1.7 \\
\hline \multicolumn{3}{|l|}{ Other non- farm occupations } \\
\hline Trading & 47 & 70.1 \\
\hline Civil service & 5 & 7.5 \\
\hline Hair dressing & 3 & 4.5 \\
\hline Teaching & 7 & 10.4 \\
\hline Catering & 1 & 1.5 \\
\hline Tailoring & 3 & 4.5 \\
\hline Artisan & 1 & 1.5 \\
\hline
\end{tabular}

Those on part-time had other non-farm occupations. They were mostly involved in pettytrading and this helps them to sustain their families during off-season periods.

Majority (50.8\%) of the farmers had access to 1-2 hectares of land while about $20.0 \%$ had $3-4$ hectares of land. Also, 27.5\% had less than 1 hectare of land while $1.7 \%$ had more than 5 hectares. This finding shows that greater proportion of the farmers had enough farmland for maize production; hence access to land is not seen as a major obstacle for their farm work. The findings are in agreement with Ali-Olubandwa et al. (2010) who observe that farmers grow maize on less than three acres of land.

A greater percentage (70.1\%) of the farmers was traders, $7.5 \%$ were civil servants, $4.5 \%$ were hair dressers while $10.4 \%$ were teachers. This result shows that farmers were seriously involved in other occupations. This is to enable them meet up with their family responsibilities, since most of them are heads of households.

*Multiple responses 


\section{Indigenous maize storage practices used by the farmers}

A greater percentage (41.7\%) of the respondent's stored maize in crib, $18.3 \%$ stored over fire in the kitchen, $16.7 \%$ stored on the floor, among others. About 3.0\% indicated that they did not store at all. This implies that they sold maize when they were fresh and had no need for storage. It could equally be that they lacked adequate storage facility and instead of allowing the maize to spoil under storage they had to sell them immediately after harvesting. The findings also indicate that the respondents had various methods of storing maize for future consumption.

Table 2. Percentage distribution of the respondents according to indigenous methods used for storing maize $(\mathrm{n}=$ 120)

\begin{tabular}{lc}
\hline Storage methods & Percentage \\
\hline Storing over fire (aerial storage) & 18.3 \\
Floor & 16.7 \\
Gourds & 1.9 \\
Earthen pots & 6.5 \\
Solid wall bins & 11.7 \\
Crib & 41.7 \\
Do not store at all & 3.3 \\
\hline
\end{tabular}

\section{Forms of storing maize}

Data in Table 3 indicate that $85.0 \%$ of the respondents stored undehusked maize, $75.0 \%$ stored dehusked maize cob, $46.7 \%$ stored shelled maize grains, while $25.0 \%$ process into flour before storage. This implies that the respondents did not store maize in forms which can be used for immediate consumption. This could be attributed to the fact that those stored in that form cannot last for a long period of time.

Table 3. Percentage distribution of respondents based on forms of storing maize $(n=120)$

\begin{tabular}{lc}
\hline Forms of storage* & Percentage \\
\hline Dehusked cob & 75.0 \\
Shelled grains & 46.7 \\
Flour & 25.0 \\
Undehusked cob & 85.0 \\
\hline
\end{tabular}

*Multiple responses

Sources of information on indigenous maize storage techniques

Table 4 indicates that fellow farmers (57.1\%) were the major source of information on indigenous maize storage techniques. Other sources of information include: neighbours (33.0\%), parents (29.7\%), and extension agents (21.7\%), among others. This implies that the respondents obtained information mostly from informal sources. The finding agrees with Anyanwu et al. (2002) who report that farmers receive their farm information from non-professional interpersonal sources more often than professional sources.

Table 4. Percentage distribution of respondents based on sources of information on indigenous maize storage techniques $(\mathrm{n}=120)$

\begin{tabular}{lc}
\hline Sources of information* & Percentage \\
\hline Fellow farmers & 57.1 \\
Extension agents & 21.7 \\
Parents & 29.7 \\
Relations & 15.0 \\
Neighbours & 33.0 \\
\hline
\end{tabular}

*Multiple responses

\section{Reasons for storing maize}

The major reasons for storing maize among farmers include: household consumption (60.0\%), generate income (40.0\%), avoidance of wastage (36.7\%) and acquisition of money during off season period. This implies that the respondents were storing maize in order to feed members of their household. This could be attributed to the fact that maize is a major staple food consumed by most households which can be used for preparing pap, flour and other diets.

Table 5. Percentage distribution of respondents according to reasons for storing maize $(n=120)$

\begin{tabular}{lc}
\hline Reasons* & Percentage \\
\hline Household consumption & 60.0 \\
Generate income & 40.0 \\
Avoid wastage & 36.7 \\
Acquire money during off & 13.3 \\
season period & \\
*Multiple responses &
\end{tabular}

\section{Constraints to effective storage of maize}

The major constraints to effective storage of maize include: poor finance $(\mathrm{M}=3.1)$, poor knowledge of preservation materials $(\mathrm{M}=3.0)$, poor access to proper storage facilities $(\mathrm{M}=2.8)$ and inadequate knowledge of better storage methods $(\mathrm{M}=2.5)$. Other constraints were moldiness of stored produce $(\mathrm{M}=2.3)$, lack of market for produce $(\mathrm{M}=2.1)$, high costs of farm inputs (2.0), among others. This implies that the respondents were highly constrained by infrastructural problems. The findings agree with Ajani and Igbokwe (2011) who report that the major constraints to crop production among farmers were lack of farm inputs such as fertilizer, herbicides, etc. However, the findings disagree with Wekesa et al. (2003) who state that technological information is not a major constraining factor to maize production in Kenya. 
Table 6. Distribution of respondents according to constraints to effective storage of maize

\begin{tabular}{|c|c|c|}
\hline Constraints & $\begin{array}{c}\text { Mean } \\
\text { score (M) }\end{array}$ & $\begin{array}{l}\text { Standard } \\
\text { Deviation } \\
\text { (SD) }\end{array}$ \\
\hline $\begin{array}{l}\text { Poor knowledge } \\
\text { of preservation } \\
\text { materials }\end{array}$ & 3.0 & 0.445 \\
\hline $\begin{array}{l}\text { Poor access to } \\
\text { proper storage } \\
\text { facilities }\end{array}$ & 2.8 & 0.553 \\
\hline $\begin{array}{l}\text { Pests and rodents } \\
\text { attack }\end{array}$ & 1.9 & 0.745 \\
\hline $\begin{array}{l}\text { Inadequate } \\
\text { knowledge of } \\
\text { better storage } \\
\text { methods }\end{array}$ & 2.5 & 0.719 \\
\hline Poor finance & 3.1 & 0.667 \\
\hline $\begin{array}{l}\text { Moldiness of } \\
\text { stored produce }\end{array}$ & 2.3 & 0.509 \\
\hline $\begin{array}{l}\text { High cost of farm } \\
\text { inputs such as } \\
\text { fertilizer and } \\
\text { herbicides }\end{array}$ & 2.0 & 0.520 \\
\hline $\begin{array}{l}\text { High cost of } \\
\text { labour }\end{array}$ & 1.8 & 0.653 \\
\hline $\begin{array}{l}\text { Lack of market } \\
\text { for produce }\end{array}$ & 2.1 & 0.523 \\
\hline
\end{tabular}

\section{Strategies for effective storage of maize}

The respondents indicated strategies that will help to alleviate the problems they encounter in maize production. They include: availability of storage facilities (93.5\%), better storage methods (87.0\%), provision of funds (84.4\%), and use of pesticides $(61.1 \%)$, among others. This implies that the farmers need to be supplied with appropriate storage technologies in order to minimize storage losses. This will in turn enhance household food security.

Table 7. Percentage distribution of respondents according to strategies for effective storage of maize

\begin{tabular}{lc}
\hline Strategies & Percentage \\
\hline Good knowledge of & 38.2 \\
preservation materials & \\
Availability of storage & 93.5 \\
facilities & 87.0 \\
Better storage methods & 61.1 \\
Use of pesticides & 10.2 \\
Adequate storage & \\
structures & 84.4 \\
\hline
\end{tabular}

\section{Conclusion and Recommendations}

Maize farmers were using indigenous storage practices such as baskets, aerial (over fire) in the kitchen, bare floors, among others in storing the packages disseminated. The farmers should be facilitated in order to adopt improved agricultural practices by providing them with soft loans, which they can use to buy farm inputs. maize. They indicated that they stored maize cobs undehusked in order to overcome wastage emanating from storage.

Efforts should be made by the government to encourage farmers to adopt improved maize storage practices in order to reduce losses emanating from storage. The educational level of the farmers should be considered when coming up with extension packages and methods to ensure maximum adoption of

\section{References}

Ajani, E.N. and Igbokwe, E.M. 2011. Implications of feminization of agriculture on women farmers in Anambra State, Nigeria. J . Agril. Ext. 15: 31-39.

Ali-Olubandwa, A.M, Odero-Wanga, D., Kathuri, N.J. and Shivoga, W.A. 2010. Adoption of improved maize production practices among small scale farmers in the agricultural reform era: The case of Western Province of Kenya. Spring. 17 (1): 25-27.

Anyanwu, A.C., Agwu, A.E. and Umeweni, C.A. 2002. Sources of agricultural information used by women farmers in Orumba North Local Government Area of Anambra State, Nigeria. ASSET Series. 2 (1): 97-104.

Collinson, M. 2001. Institutional and professional obstacles to a more effective research process for small holder agriculture. Agricultural Systems. 69 (12): 27-36.

Echezona, B.C. and Iloba, B.C. 2005. Maize earthworm attack as influences by varying maize spatial arrangement and population in maize soybean mixture. Agroscience J ournal. 4 (1): 60-65.

Eleweanya, A.N., Uguru, M.I., Eneobong, E.E. and Okocha, P.I. 2005. Correlation and path coefficient analysis of grain yield related characters in maize (Zea mays) under umudike conditions of South Eastern Nigeria. Agroscience J ournal. 4 (1): 24-28.

FAO (Food and Agriculture Organization). 2002. Special report: FAO/WFP crop and food supply assessment mission to Malawi. (http:// www.fao.org/waicent/ fao info).

Grant, I.F. and Tingle, C.C.D. 2002. Ecological monitoring methods for the assessment of pesticides impact in the tropics, Chatham, UK, National Resource Institute. p. 266.

Kodhek, G.A. 2005. Contemporary issues determining the future of Kenyan agriculture: An agenda for policy and research. Retrieved from 
http://www.yahoo.Agenda_pol_resrch(1) html.

Mochoge, B. and Zziwa, S. 2004. Agricultural and food security challenges in the IGAD region. A paper presented at the NEPAD/ IGAD regional conference Agricultural Successes in the Greater Horn of Africa. Nairobi, Kenya.

NPC (National Population Commission). 2006. National Population census figure, Abuja, Nigeria.

Nyangito, H.O. and Karugia, J.T. 2006. The impact of recent policy changes on the agricultural sector and public agricultural research in Kenya. Retrieved from http/ / :www.Glob_cho5.pdf.
Ogada, M.J . 2009. The role of production risk in farm technology adoption. Environment for Development Policy Brief.

Taylor, M. 1997. Women's work: Modern women rewrite a farm wife's job description. Top Producer. 14 (4): 8- 13.

Uguru, M.I. 1996. Crop Production Tools, Techniques and Practices, Nsukka. Fulladu publishing company, Nigeria. pp. 14-17.

UNESCO, 1991. Wekesa, E., Mwangi, W., Verkuijl, H., Danda, K. and De Groote, H. 2003. Adoption of maize production technologies in the coastal lowlands of Kenya, International Maize and Wheat Improvement Center (CIMMYT). pp. 1-34. 